\title{
Evaluation Factors Causing a Losses in the System of Receiving, Storage and Distribution Diesel Fuel in PT Badak NGL
}

\author{
Oksil Venriza ${ }^{1, *}$ Miftahul Jannah ${ }^{1}$ Tri Warcono ${ }^{1}$ Adi Luhung Pekerti ${ }^{2}$ \\ ${ }^{1}$ Logistic Oil and Gas of Department, PEM Akamigas, 58312, Blora, Central Java. \\ ${ }^{2}$ Quality Management Department, PT. Badak, NLG, 75324, East Kalimatan \\ ${ }^{*}$ Corresponding author. Email: oksil.venriza@esdm.go.id
}

\begin{abstract}
Diesel Fuel is a liquid fuel used in diesel engines. Diesel fuel is a petroleum fraction that has gone through a series of fraction separations. Petroleum is a mixture of hydrocarbons that are formed naturally. In general, in the liquid phase which is stored in the fuel sotrage tank under certain conditions. Variance is a plan or target of an outcome. The variance give an indication or a warming that the operation did not to go planned. Variance in this study devided into two possibilities, namely losses and gains. Losses are decrease in product volume (quantity)in each product movement and storage. While the gain is the increase in volume (quantity) of the product in each product movementand storage. PT Badak NGL has three diesel fuel operation categories, namely reception, hording and distribution. In the diesel fuel reception system, variance losses of $-8.25 \%$ are obtained in liters units of $15^{\circ} \mathrm{C}$. In the internal diesel fuel distribution system the loss value of 24.742 liters in observed. Based on the results of the calculation of losses, a fishbone diagram is made to analyze the factors causing losses in the company. Fishbone diagram analysis shows that there are several things the company needs to improve to reduce the possibilities of losses in the future. Based on observations made, recommendations that can be considered by companiesinclude implementation of SOPs, improve procedures considered to be lacking, addendums related to addition of clauses to limit losses, custody transfers, and determination of units used, perform maintenance of facilities and facilities in reception, hording and distribution operations, and improve employee competence by providing special diesel fuel handling training.
\end{abstract}

Keywords: Diesel fuel, Fishbone Diagram, Variance, Losses And Gain, Receiving, Storage And Distribution.

\section{INTRODUCTION}

In the implementation of natural gas processing operations at PT Badak NGL, diesel fuel has become a much needed support material for the smooth running of the company's business. PT Badak NGL obtaines diesel fuel supply from PT Pertamina through the Balikpapan fuel oil terminal. The agreement between PT Badak NGL and PT Pertamina is a LOCO agreement in which PT Pertamina is only responsible until the diesel fuel has passed throught the flange connection owned by PT Pertamina. To retrieve the diesel fuel that has been ordered, PT Badak NGL Colaborates with PT Cindara who is in charge of transporting the fuel to the delivery point. Diesel fuel is a liquid fuel used in diesel engines (as a compression engine for igniting engines) and the most common is a special fraction of crude oil distilation, generally boiling $\left.200-350^{\circ} \mathrm{C} \quad\left(392-662 \quad{ }^{\circ} \mathrm{F}\right)\right)$ at atmospheric pressure Diesel fuel is the result of a mixture of carbon chains which usually contains between eight and twenty-one carbon atoms per molecule. The density of diesel fuel is about $0.85 \mathrm{Kg} / \mathrm{L}$ [1]. Diesel fuel also contains additives in it. Additives in diesel fuel have two main functions, namely: keep the injector clean and prevent gelling in cold wather [2].

Analysis of variance is not a mathematical theorem but a simple method of refuting arithmetic facts ti isolate and display important features of a data set with utmost simplicity [3]. The variance referred to in this study is the difference that aries when recapitulating the diesel fuel volume data. This variance can be either loss or gain. Losses are the reduce volume (quantity) of product in each product movement and storage. Meanwhile, gain is 
the excees volume (quantity) of product in every movement and storage of the product [4].

A phenomenon that often occurs at PT Badak NGL is a loss in every transaction. Start from receiving at delivery point between PT Cindara and PT Badak NGL as well as internal company transactions. At the time of receiving diesel, there was a loss that exceeded the limits owned by PT Pertamina. However, PT Badak NGL does not refer to this tolerance limit. The reference used as the basis for determining losses is the contact made between PT Badak NGL and PT Cindara. Meanwhile, the problem of losses that occured internally at PT Badak NGL was indicated by the variance data in 2019 . This phenomenon occured in 2019 because data collection was only carried out in the year concerned. In the previous year, there was no variance data collection.

The problem of research devide into four parts;

a. What is the system for receiving, storage and distribution?

b. A receiving, storage and distribution system to reduce losses can implemented?

c. What are the factors that causes losses in the system of receiving, storage and distribution?

d. How to control diesel fuel to reduce the possibility of losses?

The limitation of research is just telling about diesel fuel, internal variance is only at 2019, losses in receipt of diesel fuel are only at work instruction and the stages of controlling losses do not account for costs.

The objective of research are to find out the system for receiving, storage and distribution diesel fuel, to find out the effectiveness of the system, to find out the factors causing the losses in the system and to find out how to handle diesel fuel that can minimize losses.

\section{METHOD}

The method section is written about the stage of research.

Stage 1: Problem identification. At this stage, problems from a system or condition that are already running will be sought. In this study, the problems found were losses in the system for receiving, storage and sdistribution diesel fuel. Direct interviews are also conducted related to problem that often occur. Stage 2: Literature study and data collection. At this stage data search was carried out to support evaluation related to diesel fuel losses. Data will be used to support the evaluation of factors causing losses include Bill of lading, SFAL, SFBD documents, receiving document, diesel fuel test result, initial and final tank volume in 2019, diesel fuel expenditure data, both in the system and from the pump station, SOP for receiving, storage and distribution diesel fuel, SOP for handling diesel fuel, and SOP for handling diesel fuel difference. Stage 3: Data processing. At this stage,the data previously obtained is processed using the calculation of losses which refers to PT Pertamina, and the calculation of the variance of stockpilling and distribution which refers to the SOP Procurement PT Badak NGL. Stage 4: Data analysis and interpretation of result. At this stage, if the result of data processing show losses in the system for receiving, storage and distributing diesel fuel, an analysis of the factors that cause losses is carried out using a fishbone diagram.The diagram is used to identfy all the main contributing causes likely to cause a problem. This diagram is called a fishbone diagram because the layout of the diagram resembles a fishbone. There are usually many contributors to a problem, so an effective fishbone diagram will have many potential causes listed in categories and subcategories [7]. Stage 5: Conclutions and suggestion. Conclusions are drawn from the discussion of research result as well as contributions of thoughts related to the lost control given by the researcher after making evaluations. The suggestions given are expected to be input for the company and can minimize losses in the future.

\section{RESULT AND DISCUSSION}

Calculation of diesel fuel variance volume at PT Badak NGL. Variance or difference is the difference between a plan or target of outcome. The variance gives an indication or a warning that the operation did not go as planned [8]. Variance in PT Badak divide into three parts, namely; variance of receiving, storage and distribution. Variance in this study devide into two possibilities, namely losses and gain.

\subsection{Variance of receiving}

Receiving diesel fuel in PT Badak NGL using water transportation. Calculation of losses on water transportation, especially barging, is carried out at four points which may cause excessive losses caused by technical and non-technical problems. These points include R-1 (Loading Loss), R-2 (Transport loss), R-3 (Discharge loss) and R-4 (Supply Loss). With the limits of losses that are set, namely; R1: 0.30\%, R2: 0.07\%, R3: $0.30 \%$ and R4: $0.30 \%$. The calculation is divided into 4 sections announced as follows:

\subsubsection{Loading loss}

After the fuel backloading process to the tankers and oil flow calculation is complete, the next step is to calculate losses known as loading loss (R-1), which is the difference between the Bill of Lading (B / L) number and the ship loading after figure (Ship Figure After Loading) SFAL) as stated in the After Loading Compartment 
Logsheet document issued by the ship. The formula used is as follows [5]:

To calculate loading loss, SFAL documents issued by ships are required. However, PT Badak NGL did not have the document because it did not make SFAL a mandatory document at the time of receipt of diesel fuel, so the researchers equated the Bill of Lading figures with SFAL. This results in zero loss in loading loss. However, for June 3, 2018, PT Badak has SFAL documents. So that researchers can calculate the loading loss on June 3 , 2018. The calculations for June 3, 2018, are as follows:

Known :

$\begin{array}{ll}\text { Barge name } & \text { : SPOB King Ocean } \\ \text { Unit } & : \text { Litre } 15^{\circ} \mathrm{C} \\ \text { B / L } & : 591821 \text { Litre } 15^{\circ} \mathrm{C} \\ \text { SFAL } & : 592210 \text { Litre } 15^{\circ} \mathrm{C}\end{array}$

Settlement

$\mathrm{R}-1=(\mathrm{SFAL}-\mathrm{BL}) / \mathrm{BL} \times 100 \%$

$\mathrm{R}-1=(592210-591821) / 591821 \times 100 \%$

$$
\begin{aligned}
& \mathrm{R}-1=(592210-591821) / 591821 \times 100 \% \\
& \mathrm{R}-1=389 / 591821 \times 100 \% \\
& \mathrm{R}-1=0,000657 \times 100 \% \\
& \mathrm{R}-1=0,07 \%
\end{aligned}
$$

The above calculation shows that on 3 June 2018 there was a difference between BL and SFAL. This happened because the Ship attached one SFAL document on that date. After calculating, the volume received experiences variance in the form of a gain of $0.07 \%$.

\subsubsection{Transport loss}

The value of transport loss is obtained from the difference between Ship's Figure Before Discharge (SFBD) and Ship's Figure After Loading (SFAL). Both numbers are contained in the Compartment Logsheet document according to their respective activities.The acceptance document owned by PT Badak NGL can then be used as a data reference for calculating Transport losswith the formula above. The following diagram of transport loss results calculated using the R-2 formula can be seen in Figure 1.

\section{Transport Loss}

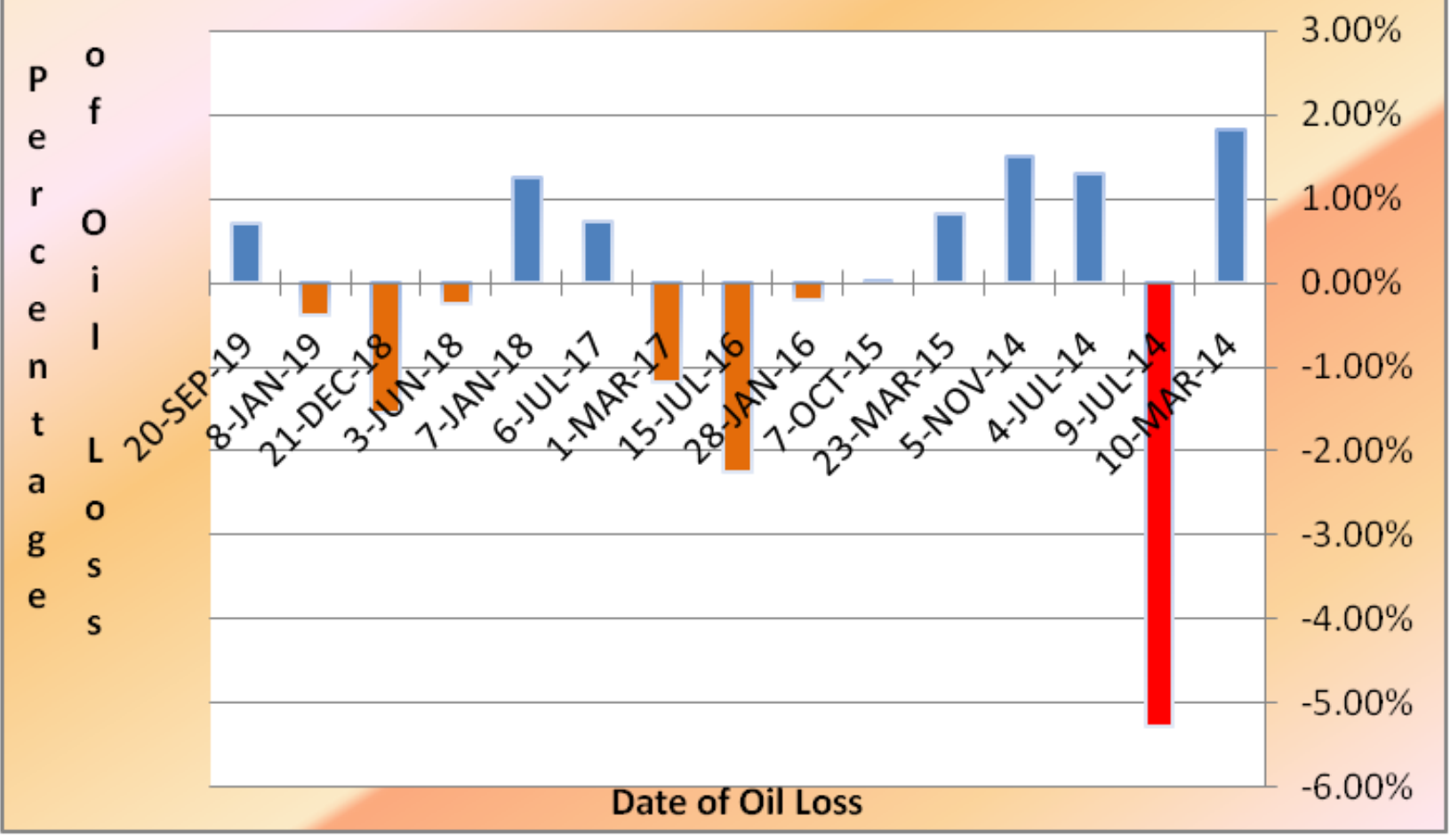

Figure 1 Transport Loss Diagram.

Losses that occur in transportation should be borne by the transporter. But the transporters objected to this so a meeting was needed to resolve the issue. Recapitulation of PT Badak NGL's transport loss for diesel fuel products can be seen in Table 1 . 
Table 1 .Transport loss, Discharge Loss and Supply Loss

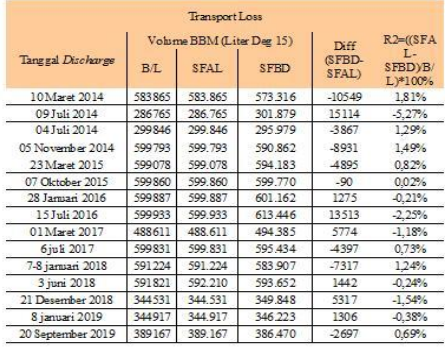

\subsubsection{Discharge loss}

Discharge loss is known as R3, which is the difference between the actual number received by the Actual Receipt tank and the vessel number before being unloaded (SFBD) at the port of discharge/discharge port [5].
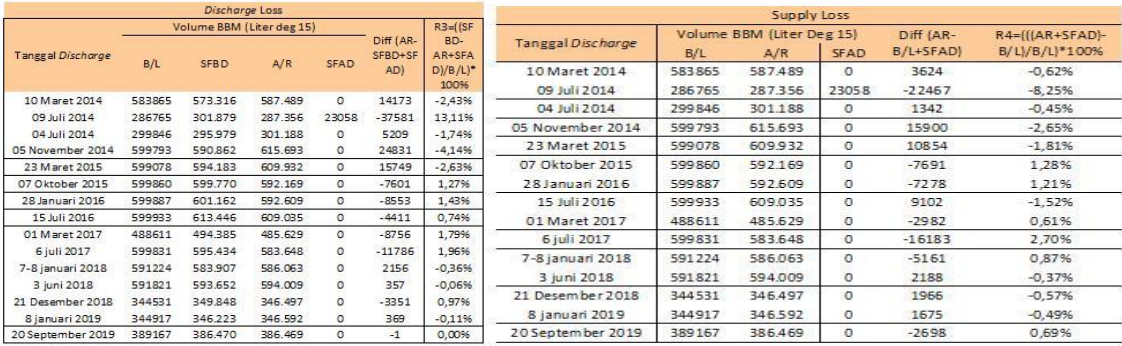

The limit of tolerance for Discharge loss is around $0.30 \%$ in standard units according to PT Pertamina's policy. If the discharge activity which has losses exceeds the tolerance limit, then a Letter of Protest is made and then the cause of the losses is made and a special report is made. Discharge loss at PT Badak NGL within approximately 6 (six) years can be seen in Figure 2 .

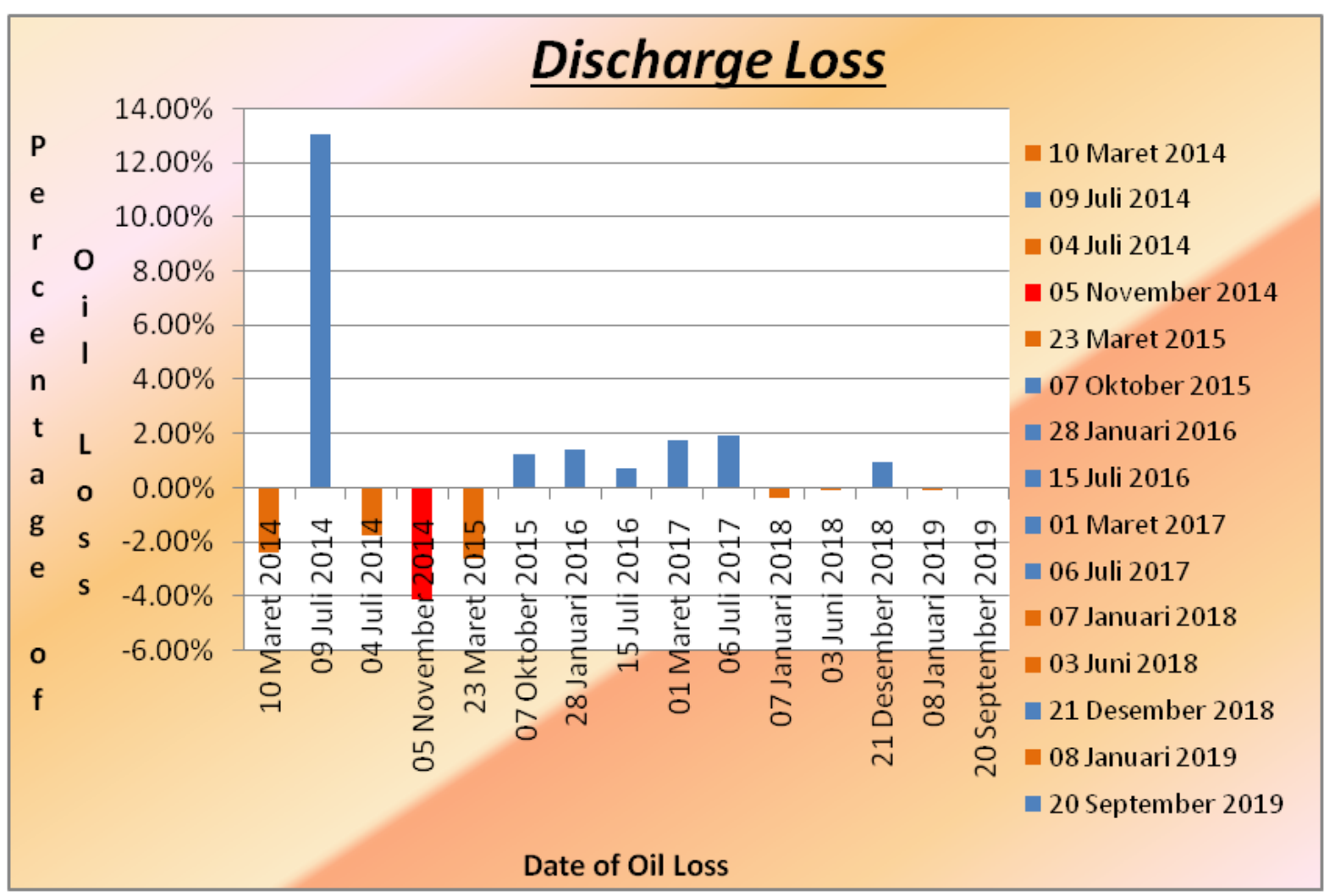

Figure 2 Discharge Loss Diagram.

Based on the bar diagram in Figure 2, several bars are shown that there have been losses at the time of receipt or commonly called Discharge Loss. On November 5, 2014, there were losses of $-4.14 \%$, on March 10, 2014. This figure largely exceeds the tolerance limit of Pertamina. The diagram also shows that there is a variance in the form of gain. The highest gain occurred on July 9, 2014, in the amount of $13.11 \%$ in standard units. The gain was made possible by errors in volume calculation, writing error, and manipulation of the ship party who only wanted to sign documents containing numbers in accordance with B / L. Not the actual number received by PT Badak NGL.

\subsubsection{Supply loss}

The emergence of losses in fuel distribution activities using the Tanker ship mode from Loading Port to Discharge Port must be kept to a minimum with a tolerance limit set by Pertamina of $0.30 \%$. For the calculation of supply loss can be seen in Appendix 2. The diagram of the results of the supply loss calculation can be seen in Figure 3. 


\section{Supply Loss}

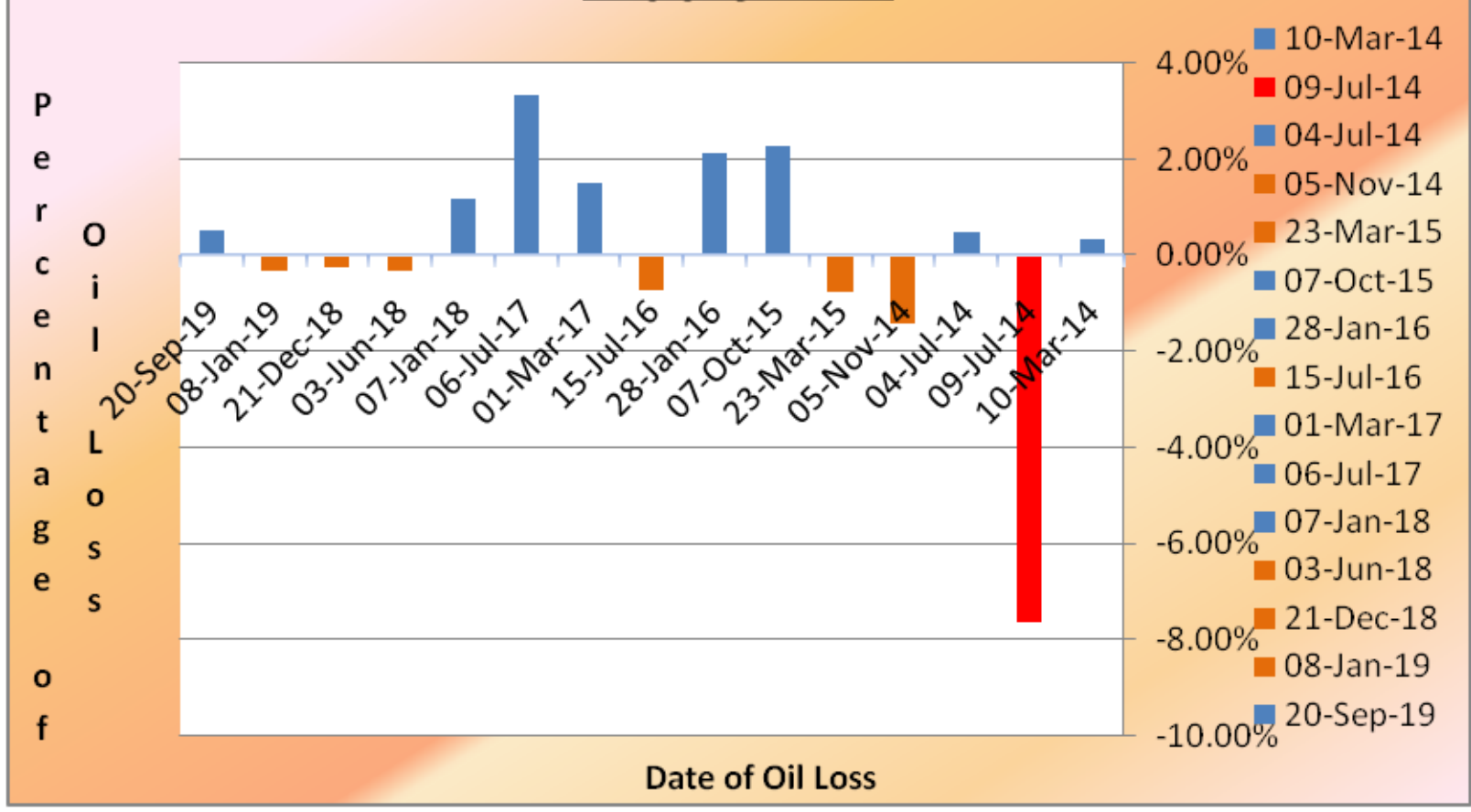

Figure 3 Supply Loss Diagram

PT. Pertamina sets tolerance limits for supply loss to monitor the achievement of losses from all loading and unloading activities, from Loading to Discharge. This can be a reference for PT Badak NGL to calculate losses when receiving fuel. The diagram above shows that the Supply that occurred during the last 6 years experienced losses and some have experienced gains. The biggest losses occurred on July 9, 2014, with a magnitude of $8.25 \%$ in Liter 15 units ${ }^{\circ} \mathrm{C}$. Besides, there are also losses in the Liter 15 unit ${ }^{\circ} \mathrm{C}$. This may occur due to errors from reading the observed density conversion table to the density at $15^{\circ} \mathrm{C}$ or error reading correction table 54, which is a table to find VCF (Volume Correction Factor) as a multiplier number to change the observed density to density at $15^{\circ} \mathrm{C}$.

\subsection{Variance of Storage}

Variance the diesel fuel hoarding is seen every month. this is because every month there is a distribution transaction in the companies internal and certain months have increased volume due to the process of receiving diesel fuel. This variance is obtained from the difference between the initial volume in the previous month compared to the final volume. At this stage, it has not been discussed about diesel fuel that is distributed. The hoarding variance is related to the channeling variance that will be compared with the total volume coming out of the stockpile tank with the volume recorded at the pump station.

\subsection{Variance of Distribution}

The variance value in the distribution can be calculated using the PT Badak NGL guidelines. The following variance data of the total transfer volume and total expenditure can be seen in Figure 4.

Based on these data, the gain and losses marked by the difference between the amount of fuel transfer and the total expenditure. Losses that occur are marked by the result of reducing fuel transfer with total expenditure in the form of gain / excess (+). While the gain occurs when the results of the reduction in fuel transfer with total expenditure in the form of losses /shortages (-). The highest variance losses occurred in September 2019 with total variance losses of 24,742 Liters. For the variance that occurs in storage and distribution using the observed unit. This variance is due to delays in inputting expenditure data into the system and delays in making manual reports. It can also be caused by a lack of coordination between departments at PT Badak NGL.

This internal variance is of particular concern because PT Badak NGL implements the procedure of no losses from diesel fuel distribution. If there is a variance, it refers to the work instructions of the Procedure for Handling Difference in the Use of Diesel Fuel in the form of Work Instruction (WI). PT Badak issued the SOP in 2018. Based on the calculation of variance in the previous sub-chapter, the distribution of diesel fuel in PT Badak NGL's internal reference to the work instructions must be carried out by balancing the load losses. The balancing 
method is used to overcome variance in 2019. Variance calculation data can be seen in Table 2. Handling using balancing makes zero loss in the distribution of diesel fuel. However, if no assessment is carried out related to the losses incurred.

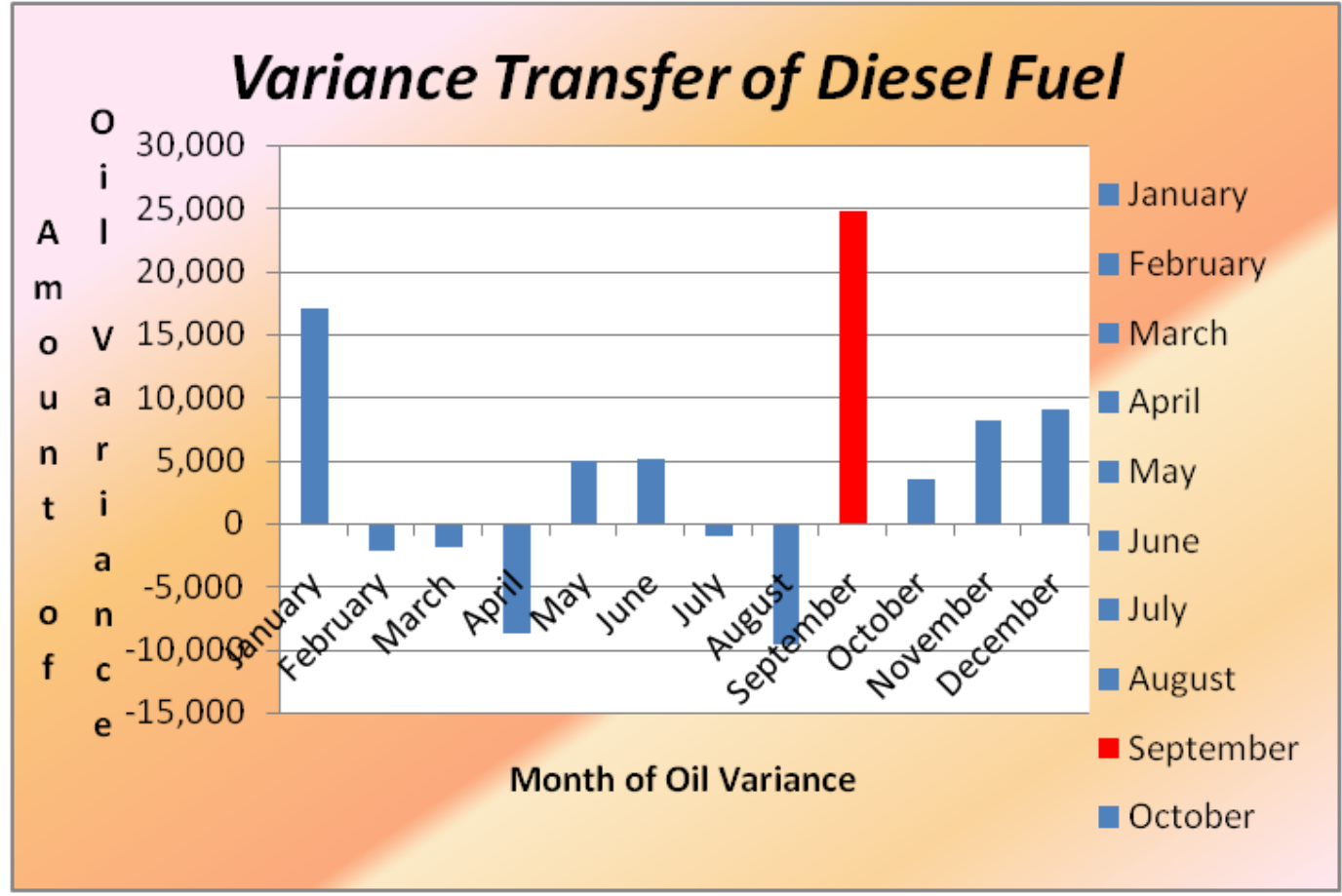

Figure 4 Diesel Fuel Variance Transfer Diagram

Table 2. Sample PT Badak NGL Internal Variance Calculation Table in January

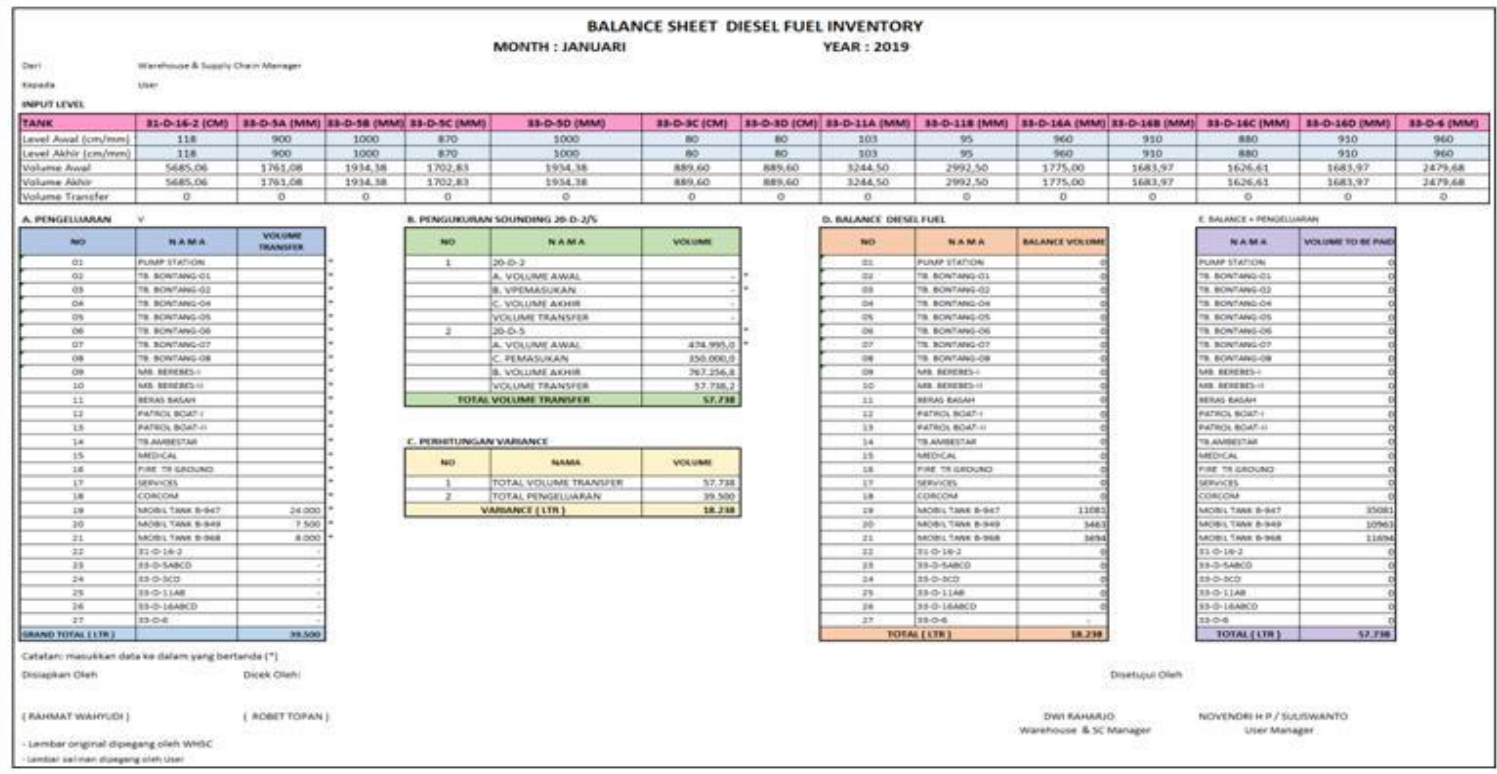

\subsection{Compilation of Fishbone Diagram}

Fishbone diagram This will be made to determine the cause of the problems that affect variance of diesel fuel. Based on observations using the Systems,
Administration, Reception, Storage, Distribution, and Environment approach the observer can compile a fishbone diagram. This fishbone diagram discusses the effects that occur from the cause approach is variance losses. The arrangement of the fishbone diagram can be seen in Figure 5. 


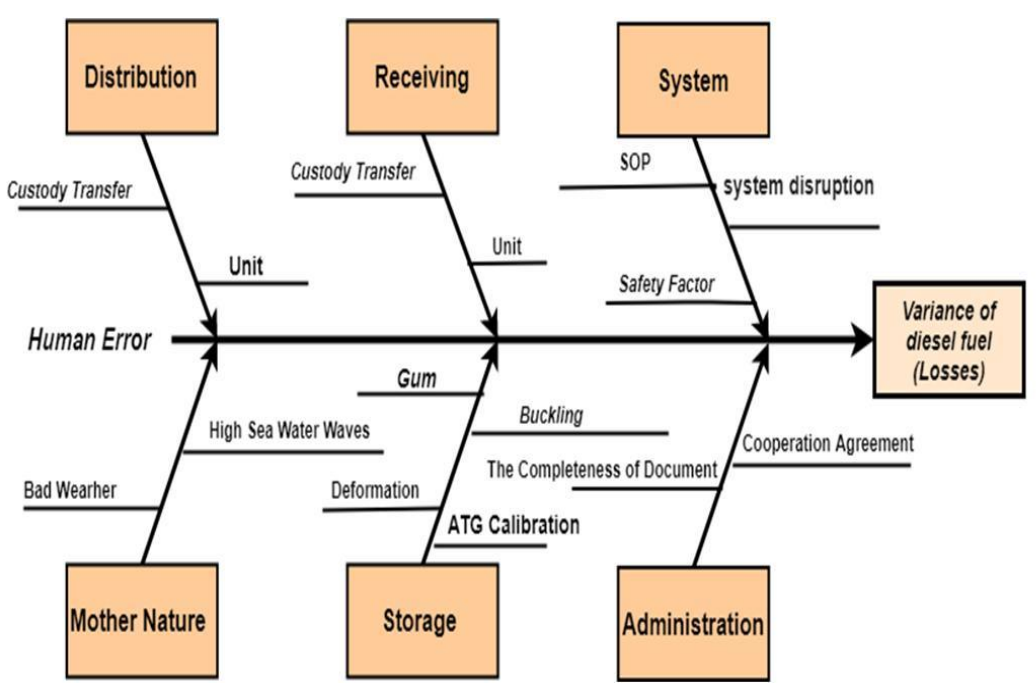

Figure 5 Fishbone Diagram of Diesel Fuel Variance (Source: Research Document)

The factors that cause losses based on fishbone diagrams are as follows:

\subsubsection{System}

\subsubsection{Human error}

a) Officers do not yet have a special certificate related to handling diesel fuel so that the process of receiving, hoarding, and distributing diesel fuel is not following the Standard Operating Procedure (SOP).

b) Error inputting diesel fuel volume data on the Enterprise Resource Planning (ERP) system.

c) Late reporting on transactions during distribution in the Enterprise Resource Planning (ERP) system.

\subsubsection{Standard Operating Procedure (SOUP)}

a) The unavailability of Standard Operating Procedure (SOP) related to bounding cable and grounding cable (safety factor) in the process of receiving diesel fuel.

b) The unavailability of Standard Operating Procedure (SOP) for measuring oil volume in both land tanks and ship compartments.

c) There is no Standard Operating Procedure (SOP) related to sampling and quality control.

d) There is no Standard Operating Procedure (SOP) related to transaction flow at the time of distribution.

\subsubsection{Safety Factor}

a) Payless attention to safety factors in the Reception, Hoarding, and Distribution systems.

\subsubsection{System Disruption}

a) Network system disruption when inputting diesel fuel volume data and reporting on diesel fuel distribution transactions.

\subsubsection{Administration}

\subsubsection{Human error}

a) Does not include vessel document requirements related to diesel fuel volume calculations.

b) Not re-checking the results of the volume calculation conducted by the surveyor.

3.4.2.2. The completeness of the document

a) Incomplete ship documents (SFAL, NOR, Cargo Manifest, and CQL).

\subsubsection{Cooperative contract}

a) There is no explanation of the density used at the receiving.

b) Limitation tolerance of $0 \%$. Without considering pseudo losses.

c) Unclear transfer custody stated in the cooperation contract.

\subsubsection{Reception}

\subsubsection{Human error}

a) Not checking the completeness of safety equipment on the ship.

b) Does not measure the contents of the overall compartment volume, only the sample.

c) Error reading conversion table. 
d) Error input Volume Correction Factor (VCF) in the calculation of vessel compartment volume.

e) Conduct density measurements and temperature measurements in only one ship compartment.

f) Payless attention to installing the hose with the flowmeter.

g) Error reading volume on the measuring tape at the time of measurement and error reading density on the densitometer.

\subsubsection{Custody Transfer}

a) Unclear transfer custody points, namely between ship flowmeter, PT Badak NGL flowmeter, and manual calculation from the surveyor (PT Sucofindo).

b) Damage to the PT Badak flowmeter so that it only uses ship flowmeter and PT Sucofindo manual calculation.

\subsubsection{Unit}

a) Using the liter observed as a unit of receipt of diesel fuel.

\subsubsection{Stockpiling}

\subsubsection{Human error}

a) Officers do not yet have a special certificate related to the measurement of diesel fuel volume in storage tanks.

b) The clerk does not measure the volume before and after the transaction.

c) Officers take measurements of the volume during the distribution transaction.

\subsubsection{Deformation}

a) The tank is not calibrated allowing the occurrence of deformation phenomena on the pile tank foundation.

\subsubsection{Buckling}

a) The tank is not calibrated it is possible that the Buckling phenomenon occurs on the wall of the storage tank.

\subsubsection{Gum}

a) The tank is not calibrated it is possible to occur deposition (gum) at the bottom of the storage tank.

\subsubsection{Automatic Tank Gauging (ATG) Calibration}

a) Automatic Tank Gauging(ATG) not calibrated periodically is possible inaccurate reading of the volume of diesel fuel.

\subsubsection{Distribution}

\subsubsection{Human error}

a) Officers do not yet have a special certificate related to handling fuel.

b) Conducting distribution transactions in two departments simultaneously.

c) Error reading total distribution volume and data collection error.

\subsubsection{Custody Transfer}

a) Unclear delivery point/custody transfer point which is the reference for distribution.

b) There is no flowmeter in one of the storage tanks for distribution to consumers (Fire Tr Ground).

c) Damage to one of the flow meters in the path to the consumer (Tugboat).

\subsubsection{Unit}

a) The transaction unit used is not a standard liter 15 unit ${ }^{\circ} \mathrm{C}$ but the liter unit is observed.

\subsubsection{Mother Nature}

\subsubsection{Human error}

a) Conduct loading and unloading during bad weather

\subsubsection{Bad weather}

a) Disassembling when it rains.

b) Dismantling the load when it is sweltering

\subsubsection{High Sea Water Waves}

a) Carrying out the reception process during high tide water waves can cause diesel fuel in the shipping compartment to be unstable.

\subsection{Variance Control System (Losses)}

Based on observations presented in the form of a fishbone diagram, visible factors of the occurrence of losses or gains in the system of reception, hoarding, and distribution of diesel fuel caused by many factors and can be said to be unavoidable, but these losses can be minimized. To minimize losses that occur need to be considered the following things: 


\subsubsection{System}

- Human error

a. Increase human resources by mobilizing employees to conduct training and certification related to handling fuel and calculating fuel volume (Tanker loading master).

b. Improve human resources by mobilizing employees to conduct training and certification related to the operation of the Resource Planning (ERP) system

- Standard Operating Procedure (SOP)

a. Add safety equipment completeness to the Standard Operating Procedure (SOP) in the process of receiving diesel fuel.

b. Develop Standard Operating Procedure (SOP) related to the measurement of oil volume both in storage tank and ship compartments.

c. Develop Standard Operating Procedure (SOP) related to sampling and quality control

d. Adding transaction flow to the Standard Operating Procedure (SOP) for diesel fuel distribution.

- Safety Factor

a. Reviewing SOPs and affirming priority in occupational health and safety. Especially in the system of reception, hoarding, and distribution of diesel fuel.

- System Disruption

a. Ensure the network system is not problematic at the time before making a transaction and after making a transaction.

\subsubsection{Administration}

- Human error

a. Check documents in detail (checklist document)

b. Re-checking the results of the volume calculation conducted by the surveyor and participating in the calculation process.

- The completeness of the document

b. Add acceptance document requirements (SFAL, NOR, and Certificate of Quantity Load (CQL), Manifest, Certificate of Quality (COQ), and Loading Agreement).

- Cooperative contract

a. Addendum and add clauses about density used, tolerance limits, and custody transfers. If it cannot be done addendum, it can enter into a new cooperation contract with the transporter who wins the tender by still entering the points.

\subsubsection{Reception}

- Human error

a. Increase human resources by mobilizing employees to conduct training and certification related to the calculation of fuel volume in the shipping compartment (Tanker loading master).

b. Check the completeness of the safety factors before making the admission process.

c. Measuring diesel fuel volume, inside temperature, outside temperature, and density in all ship compartments.

- Custody Transfer

a. Check, repair, and calibrate the PT Badak NGL flowmeter and the ship flowmeter.

- Unit

a. Change the observed liter into a standard unit (liter 15 ${ }^{\circ} \mathrm{C}$ ) as a unit of acceptance transaction.

\subsubsection{Stockpiling}

- Human error

a. Increase human resources by mobilizing employees to conduct training and certification related to the calculation of the volume of fuel in storage tanks.

b. Measuring the volume before and after the transaction both on the receipt transaction and the distribution transaction.

c. Ensure that there are no other processes when measuring the volume in the land tank, ensuring there are no other transactions when making a receipt transaction. Likewise at the time of distribution.

- Deformation, Gum, and Buckling

a. Perform tank calibration.

b. Implementing quality control products regularly.

- Automatic Tank Gauging (ATG) Calibration

a. Perform Automatic Tank Gauging (ATG) calibration.

\subsubsection{Distribution}

- Human error

a. Improve human resources by mobilizing employees to conduct training and certification related to handling fuel.

b. Ensure that at the time of conducting the transaction there are no other distribution transactions carried out simultaneously.

- Custody Transfer 
a. Determine the delivery point/custody transfer that becomes the reference for distribution.

d) Conduct a flowmeter in the storage tank output for distribution to consumers (Fire Tr Ground).

b. Perform calibration of the existing flowmeter

- Unit

b) The transaction unit used is 15 liter standard units ${ }^{\circ} \mathrm{C}$ is not a liter unit observed

\subsubsection{Environment}

a. Paying attention to weather factors at the time of the transaction, both acceptance, measurement of vulome in the hoarding, and distribution.

b. Paying attention to waves of seawater so as not to carry out the reception process when fuel in the shipping compartment is not yet stable.

\section{CONCLUSION}

The variance control system that has been implemented is not yet fully following existing procedures. Evidenced by the presence of variance diesel fuel. The variance that occurs in the recapitulation of diesel fuel volume calculation is divided into 3 parts, namely: receiving variance, storage variance, and distribution variance.

The difference in load occurs due to several factors, such as technical and non-technical factors. Besides, natural factors can also affect losses that occur at the time of receipt. The biggest difference occurred in 2014 with a total loss of $-8 \%$. This figure has exceeded the tolerance limits of Pertamina. However, PT Badak NGL has not set losses limits because all travel losses are borne by the transporter. In storage and distribution, the variance was seen during the distribution process with the highest total variance losses in September with a total loss of 24,732 Liters.

The design of the control system can be made based on the results of the analysis drawn through the fishbone diagram. By paying attention to the factors causing variance through the system, administration, receiving, storage, distribution, and mother nature. A very influential factor in the whole process is human error due to a lack of understanding related to handling BBM products.
3. Improving the variance control system can be done based on the factors described in the fishbone diagram by carrying out the stages through the System, Administration, Receiving, Storage, Distribution, and Mother Nature. Starting from increasing human resources, an addendum to cooperation contracts and adding clauses, making SOPs, performing calibrations on facilities, and paying attention to weather factors when receiving diesel fuel.

\section{ACKNOWLEDGMENT}

The authors would like to thank's the PEM Akamigas for the sponsor. This work was financially supported by the unit UPPM of PEM Akamigas and PT. Badak LNG The author is deeply indebted to the many co-workers whose names appear in the references.

\section{REFERENCES}

[1] J.G.Speight, CD and Winc "Woodhead Publishing in United Kingdom," Production, Properties and Environmental Impact of Hydrocarbon Fuel Conversion, 2011.

[2] Shekhawat, Dushyan, James J Spivey, and David A Berry, "Elsevier in Amsterdan, The Netherlands," Tata Fuel Cells Technologies for Fuel Processing, 2011

[3] R,Shayle Searle, George Casella, Charles E.McCulloch, "John Wiley \& Sons, Inc in Canada," Variance Components, 2006

[4] PT. Pertamina, "Direktorat Pemasaran dan Niaga in Jakarta," Pengelolaan Kuantitas Produk BBM. Rev.O, no. A004 /F10300/2014-S3, 2014

[5] PT. Pertamina, "Direktorat Pemasaran dan Niaga in Jakarta," Supply and Distribution: Direktorat Pemasaran dan Niaga, 2014

[6] PT. Badak NGL, "PT Badak NGL in Kalimantan Timur," Work Instruction : Tata Cara Penanganan Selisih Penggunaan Diesel fuel, 2018

[7] P, Dennis Nolan, "Elsevier Inc in USA.," Safety and Security Review for the Process Industries: Chapter 5,2015

[8] Witjaksono, Armanto, "Graha Ilmu in Yogyakarta.," Akuntansi Biaya, Edisi Revisi, 2013. 